\title{
Temporal patterns of carbon flow from grassland vegetation to soil microorganisms measured using 13C-labelling and signature fatty acids
}

\author{
Johanna Birgander • Pål Axel Olsson (1)
}

Received: 1 December 2020 / Accepted: 19 January 2021 / Published online: 8 February 2021

(C) The Author(s) 2021

\begin{abstract}
Purpose We investigated how the $\mathrm{C}$ flow from plants to microorganisms varies throughout the year in a temperate grassland. Additionally, we investigated how the $\mathrm{C}$ flow relates to saprotrophic activity and vegetation changes.

Methods In situ stable isotope pulse labelling $\left({ }^{13} \mathrm{CO}_{2}\right)$ was employed to estimate the flow of recently plantderived $\mathrm{C}$ to soil microorganisms by using signature fatty acids. Bacterial and fungal growth was estimated using radio-labelling in laboratory incubations.

Results The C flow from plants to arbuscular mycorrhizal (AM) fungi peaked during the warmer parts of the year, but saprotrophic microorganisms showed little temporal variation in $\mathrm{C}$ flow. Also saprotrophic fungi received considerable amounts of $\mathrm{C}$ from plants throughout the year. Bacterial and fungal growth showed temporal variation with a growth peak in $\mathrm{Au}-$ gust for both. This suggests a shift in the C source from mainly rhizosphere $\mathrm{C}$ in colder parts of the year, to older $\mathrm{C}$-sources in warmer parts of the year (August).

Conclusion We conclude that AM fungi, saprotrophic fungi and bacteria differ in the amount of recently-fixed $\mathrm{C}$ they receive from plants throughout the year. Hence, temporal patterns need to be considered to understand ecosystem functioning. The studied plant community
\end{abstract}

Responsible Editor: Tatsuhiro Ezawa

J. Birgander · P. A. Olsson $(\varangle)$

Biodiversity, Department of Biology, Lund University,

Sölvegatan 37, SE-223 62 Lund, Sweden

e-mail: Pal_Axel.Olsson@biol.lu.se included winter annuals, which potentially maintain a high $\mathrm{C}$ flow to saprotrophic fungi during the cold season.

Keywords Arbuscular mycorrhiza (AM) · Fatty acids . Rhizosphere $\cdot$ Season $\cdot$ PLFA, ${ }^{13} \mathrm{C} \cdot$ Temporal patterns

\section{Introduction}

In temperate ecosystems, seasonality in temperature and light affects plants, microorganisms and their interactions. Both plants and microorganisms can be active during the winter season, despite low temperatures (Brooks et al. 1997). The winter season is often overlooked, which may limit our understanding of important ecosystem functions (Campbell et al. 2005; Kreyling 2010; Makoto et al. 2014; Kreyling et al. 2019).

Photosynthetic activity is low during the winter because of low temperature, but also because of reduced light availability and soil moisture (Flanagan and Johnson 2005). However, plants can still photosynthesise during the cold season, and photosynthesis has been measured at temperatures as low as $0{ }^{\circ} \mathrm{C}$ (Larsen et al. 2007). Carbon (C) assimilation (Lekberg et al. 2013) and nitrogen (N) uptake (Andresen and Michelsen 2005; Groffman et al. 2001) in plants have been shown to occur in temperate ecosystems during the cold season. In addition, soil respiration can be substantial in winter climate, often under a snow cover (Brooks et al. 1997; Alm et al. 1999; Larsen et al. 2007). 
The feedback between plants and soil microorganisms are fundamental to the global $\mathrm{C}$ cycle, and these feedback mechanisms are partly influenced by temperature (Lloyd and Taylor 1994). Plants contribute with C sources to soil microorganisms both through litter fall and rhizodeposition, and microorganisms make nutrients available for the plants through decomposition. Plants and microorganisms may also compete for the same nutrients, and this competition varies seasonally (Bardgett et al. 2003). The plant community composition can influence the microbial community composition, not only through variation in litter quality, but also because different plants offer different niche opportunities for the microorganisms (Fry et al. 2016), and because plants preferentially allocate $\mathrm{C}$ to beneficial microorganisms (Bever et al. 2009).

An important and beneficial group of microorganisms in grasslands are arbuscular mycorrhizal (AM) fungi, which supply nutrients to plants in exchange for $\mathrm{C}$ as part of a close symbiotic relationship. There is a lack of knowledge about how AM fungi grow and function in cold climates, but plants have been shown to benefit from AM fungi even at low temperatures (Tibbett and Cairney 2007). Lekberg et al. (2013) found that $\mathrm{AM}$ fungi receive plant-derived $\mathrm{C}$ also during the colder months of the year in a temperate coastal grassland, and that similar amounts of $\mathrm{C}$ were allocated to AM fungi in late autumn as in summer.

Soil bacteria and saprotrophic fungi are also influenced by annual climate variation (Bardgett et al. 1999; Birgander et al. 2014) since temperature is an important regulator for heterotrophic respiration (Bárcena-Moreno et al. 2009; Birgander et al. 2013; Walksman and Gerretsen 1931). Still, soil respiration has been detected even at temperatures as low as $-5{ }^{\circ} \mathrm{C}$ in a laboratory study (Clein and Schimle 1995). Saprotrophic fungi are suggested to be relatively more dominant compared to bacteria during winter (Lipson et al. 2002) and to have a greater potential to be active during the colder months (Birgander et al. 2014).

More than $90 \%$ of the total soil microbial biomass has been suggested to be inactive (Blagodatskaya and Kuzyakov 2013), and dormancy likely varies over the year (Jones and Lennon 2010). Therefore, biomassbased measurements may not always be relevant for studies of temporal variation of microorganism importance. The use of in situ pulse labelling with stable carbon isotopes, in combination with biomass signature compounds, enables tracing of $\mathrm{C}$ from the atmosphere to the soil microorganisms via plants (Olsson and Johnson 2005).

We investigated how different groups of microorganisms vary in their uptake of recently-derived plant $\mathrm{C}$ throughout the year, and how variation relates to microbial biomass, growth rates and vegetation composition. We hypothesized (1) that the plant-derived C in AM fungi would increase from the first time point that was in March (early spring) to the time points in June and August (representing the warmer season), and then decrease gradually again to October and then further during the cold season. We also expected (2) that a higher flow of $\mathrm{C}$ from plants to AM fungi would result in a higher AM fungal biomass. Incorporation of plantderived $\mathrm{C}$ into bacteria and saprotrophic fungi was hypothesized (3) to show less temporal variation as they are less directly dependent on plants, and plant-derived $\mathrm{C}$ would thus peak in late August when plants are about to wilt and have less need for $\mathrm{C}$ for plant growth.

\section{Materials and methods}

\section{Site description and sampling}

Our study site was located in southern Sweden (N $55^{\circ}$ $42^{\prime}$; E $14^{\circ} 10^{\prime}$ ), in a temperate grassland with low grazing intensity $\left(0.5 \mathrm{cow} \mathrm{ha}{ }^{-1}\right)$ that had not received commercial fertilizer. The soil was classified as Eutric Cambisol according to the FAO system (Jones et al. $2005)$ and it was well drained. The vegetation consisted of mosses, grasses and low forbs. A $20 \times 20$ m study plot was established in an area on flat ground that was visually judged to be as homogenous as possible and with the same vegetation type throughout (see Table S1 for species composition). Within this study plot we established 30 evenly distributed subplots (each $24 \times$ $43 \mathrm{~cm}$ ). We performed five pulse-labelling events between March 2011 and March 2012 (March 30, June 8, August 18 and October 24 in 2011, and March 16 in 2012). In the region of the study, in March it is early spring (but winter climate my still prevail), in June it is early summer, in August it is late summer and in October it is autumn. At each sampling time, six subplots were randomly assigned for labelling. No subplot was labelled more than once. Our study design includes replication within a relatively homogenous grassland plot, but it does not represent ecological replication across environmental gradients. Air temperature data 
(mean annual temperature the week before sampling) was retrieved from Swedish Meteorological and Hydrological Institute for the weather station Skillinge (N $55^{\circ}$ 49'; E 14 31'). The warmest time-points sampled were June and August. In March 2011, the air temperature was lowest and was recorded as $4.1{ }^{\circ} \mathrm{C}$ the week before the labelling (Table 2). Vegetation analysis was performed on the same day as the pulse-labelling was performed, and soil and plant samples for isotopic analyses were collected 5 and 9 days (chase periods) after labelling. The 5-day soil samples were also used for analysing microbial biomasses and soil chemistry.

${ }^{13} \mathrm{CO}_{2}$ labelling in the field

Pulse labelling of the vegetation with ${ }^{13} \mathrm{CO}_{2}$ was carried out at five time points (see above). Transparent plastic hoods $(35 \times 20 \times 12 \mathrm{~cm})$ were placed over the entire vegetation at each of the six randomly assigned subplots, ensuring airtight conditions. A pulse of $50 \mathrm{ml}$ $99.9 \%{ }^{13} \mathrm{CO}_{2}$ gas (Cambridge Isotope Laboratories, Tewksbury, MA, USA) was injected into each hood using a gas syringe and then the hoods were sealed. The pulse period lasted for two hours and then the hoods were removed. Light intensity, estimated as photosynthetic photon flux density, was monitored during the pulse period, and labelling was performed at mid-day on days with a clear sky. Soil was collected with a soil corer $(3 \mathrm{~cm} \varnothing)$ to $5 \mathrm{~cm}$ depth five days and nine days after labelling. Earlier studies in this area has shown that the A horizon is thin, and extending the sampling beyond $5 \mathrm{~cm}$ would also include a large part of relatively pure mineral sand. Two cores from each subplot (taken centrally at $20 \mathrm{~cm}$ distance) were combined into one composite sample (to reduce the number of samples) and brought back to the lab on ice for storage at $-20^{\circ} \mathrm{C}$ until further analysis.

Fatty acid analysis and ${ }^{13} \mathrm{C}$ enrichment

Soil for analysis of fatty acid content was kept at $-20{ }^{\circ} \mathrm{C}$ until all samples were collected, and they were analysed randomly for fatty acid content and stable isotopes in October-December 2012. Storage at $-20^{\circ}$ is considered appropriate for lipid analysis (Frostegård et al. 1991). Lipids were extracted according to Frostegård et al. (1993), using $5 \mathrm{~g}$ freeze-dried soil, extracted in a onephase mixture of chloroform, methanol and citrate buffer, for two hours. Extracted lipids were fractionated into neutral, intermediate and polar lipids by eluting with chloroform, acetone, and methanol, respectively, on pre-packed silica columns (van Aarle and Olsson 2003). The neutral and polar lipids (containing phospholipids) were subjected to mild alkaline methanolysis using fatty acid methyl ester 19:0 (for fatty acid taxonomy, see Tunlid and White 1992) as the internal standard and analysed on a gas chromatograph (Frostegård et al. 1993).

The bacterial biomass indicators were phospholipid fatty acids (PLFAs) i15:0, a15:0, i16:0, 16:1 $\omega 9$,

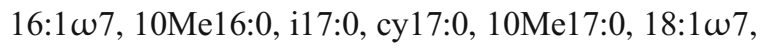
10Me18:0 and cy19:0 (Frostegård and Bååth 1996). PLFA 18:2 $\omega 6,9$ was used as the indicator of ascomycetes and basidiomycetes and thereby mainly indicates saprotrophic fungi in grasslands (Frostegård and Bååth 1996). The neutral lipid fatty acid (NLFA) $16: 1 \omega 5$ was used as the AM fungal biomass indicator. It has been shown to be more sensitive as an AM fungal signature and correlate better than PLFA 16:1 $1 \omega 5$ with other indicators of AM fungal biomass, such as hyphal length density and root colonisation (Olsson et al. 1995; Olsson et al. 1998; Ven et al. 2020).

The flow of recently plant-fixed $\mathrm{C}$ to microorganisms was quantified by measurements of ${ }^{13} \mathrm{C}$ in extracted PLFA and NLFA on a Delta IV Plus isotope ratio mass spectrometer (IRMS) coupled to a Trace GC Ultra gas chromatograph via the ConFlow IV interface (Thermo Fisher Scientific, Bremen, Germany) at the Stable Isotope Facility at the Department of Biology, Lund University, Sweden. The $\delta^{13} \mathrm{C}$ values were calibrated against the Pee Dee Belemnite (PDB) standard and corrected for the extra non-labelled methyl group from the methanolysis (eq. 1),

$$
\left(\mathrm{nC} * \delta^{13} \mathrm{C}+\mathrm{Me}\right) /(\mathrm{nC}+1)
$$

where $\mathrm{nC}$ is the number of carbon in the fatty acid chain, and $\mathrm{Me}$ is the average $\delta^{13} \mathrm{C}$ in methanol. Thereafter samples were corrected for background ${ }^{13} \mathrm{C}$ from nonlabelled samples (eq. 2), giving the excess ${ }^{13} \mathrm{C}$ in the fatty acids,

$\delta^{13} \mathrm{C}-\delta^{13} \mathrm{C}_{\text {background }}$

where $\delta^{13} \mathrm{C}_{\text {background }}$ is the measured $\delta^{13} \mathrm{C}$ in nonlabelled samples ( $n=5$ and 8 for NLFA and PLFA, respectively). The non-labelled controls were the same as used in another study from the same grassland, and the exact values are published in Birgander et al. (2017). 
Growth of bacteria and saprotrophic fungi

Soil was collected on the fifth day after pulse labelling, on each of the five labelling time points, and bacterial and fungal growth was analysed within $24 \mathrm{~h}$ of sampling. To standardize for the variation in soil temperature over the year, soil was kept on ice during handling and incubations for growth measurements were conducted at $14{ }^{\circ} \mathrm{C}$.

Bacterial growth was estimated according to Bååth et al. (2001). Briefly, $1 \mathrm{~g}$ soil was mixed with $20 \mathrm{ml}$ water and centrifuged at $1000 \times \mathrm{g} .1 .5 \mathrm{ml}$ of the supernatant (containing soil bacteria) was incubated with $2 \mu$ radioactively labelled leucine $\left(\left[{ }^{3} \mathrm{H}\right] \mathrm{Leu}\right.$, $185 \mathrm{MBq} \mathrm{ml}^{-1}, 2 \mathrm{TBq} \mathrm{mmol}^{-1}$, Perkin Elmer) and $2 \mu \mathrm{l}$ of $200 \mathrm{mM}$ unlabelled leucine, resulting in a concentration of $275 \mathrm{nM}$ in the suspension. After $3 \mathrm{~h}$ of incubation at $14{ }^{\circ} \mathrm{C}$, growth was terminated by addition of $75 \mu 1100 \%$ TCA. Samples were washed prior to measuring the incorporated radioactivity using liquid scintillation, which was then used as a proxy for bacterial growth.

Fungal growth was estimated using the acetate-inergosterol incorporation method, according to Bååth (2001), and modified by Rousk et al. (2009). Briefly, $1 \mathrm{~g}$ soil was incubated with $20 \mu \mathrm{l} 1-\left[{ }^{14} \mathrm{C}\right]$ acetic acid (sodium salt, $37 \mathrm{MBq} \mathrm{ml}^{-1}, 2.10 \mathrm{GBq} \mathrm{mmol}^{-1}$, Perkin Elmer), $480 \mu \mathrm{l}$ unlabelled $1 \mathrm{mM}$ acetate and $1.5 \mathrm{ml}$ water, resulting in a final concentration of $220 \mu \mathrm{M}$. After about $5 \mathrm{~h}$ of incubation at $14{ }^{\circ} \mathrm{C}$, growth was terminated by adding $1 \mathrm{ml} 5 \%$ formalin. Ergosterol was extracted and quantified with HPLC (UV detector, $282 \mathrm{~nm}$ ), and collected using an automated fraction collector. Radioactivity incorporated into ergosterol was used as a proxy for fungal growth after measurement using liquid scintillation.

\section{Soil analyses}

Soil organic matter (SOM) content was determined gravimetrically as loss on ignition (LOI) on dried samples $\left(5 \mathrm{~h}, 550{ }^{\circ} \mathrm{C}\right)$, assuming $\mathrm{LOI}=$ total soil organic matter content. Ammonium $\left(\mathrm{NH}_{4}{ }^{+}\right)$and nitrate $\left(\mathrm{NO}_{3}{ }^{-}\right)$ were extracted from soil within $24 \mathrm{~h}$ after sampling, in $0.1 \mathrm{M} \mathrm{BaCl}_{2}$ (1:5) and measured using flow injection analysis for soil samples from June 2011, August 2011 and March 2012, while data is missing for the other time points.
Vegetation analysis

In connection to pulse labelling, the vegetation was surveyed in $1 \mathrm{~m}^{2}$ plots. In four replicated plots, coverage of vascular plants, mosses and lichens was estimated. Identification to species was undertaken in most cases, however, some families where species were hard to distinguish were identified to family level (see supplementary Table 1). Plant species were classified as perennial, summer annuals or winter annuals if possible, according to classification by Grime et al. (1996). The mycorrhizal status of plants was classified according to Harley and Harley (1987). The functional classification was used to independently calculate the proportion non-mycorrhizal species as well as the proportion annual species.

\section{Statistical analyses}

Temporal variation of ${ }^{13} \mathrm{C}$ enrichment was tested at day 9 , since the enrichment was in nine out of 15 cases (Table 1) highest 9 days after pulse labelling. Variations of ${ }^{13} \mathrm{C}$ enrichment, growth rates, and biomass between time points were tested with one-way ANOVA with date as group variable, and when significant, a Tukey post hoc test was used to identify which time points had differed significantly. To test for differences between sampling days, i.e. between sampling 5 and 9 days after pulse labelling, a paired t-test was used. All data were tested for equal variance, and ${ }^{13} \mathrm{C}$ enrichments and growth rate measurements were log transformed to fulfil the assumptions for statistical analysis. A correspondence analysis was performed to assess vegetation changes. The first two axes were tested for temporal variation with repeated measures ANOVA. Data were square root transformed to obtain equal variance and time was used as within subject factor.

All statistical analyses were performed in SPSS (SPSS Statistics, IBM Corporation, New York, USA), Correspondence analysis (CA) of the vegetation composition were performed in CANOCO 4.5 (Ter Braak and Smilauer 2002), and graphs were constructed using KaleidaGraph (Synergy Software, Reading, USA).

\section{Results}

All microbial indicators showed ${ }^{13} \mathrm{C}$ enrichment, showing that the in situ ${ }^{13} \mathrm{C}$ labelling was successful. The 
Table 1 The percent ground coverage was estimated at five time points over the course of one year. Values represent the mean of 4 replicates \pm SE. Plants were classified as annuals or perennials according to Grime et al. 1996 or Tyler et al. 2021, and mycorrhizal status was classified according to Harley and Harley (1987).
From this, the proportion of annuals and non-mycorrhizal (NM) vegetation cover was calculated independently (see Table S1 for classification of species in this study). Different letters indicate significant difference between time points $(p<0.05)$ tested with one-way ANOVA and Tukey post hoc test

Time of the year

\begin{tabular}{llllll}
\cline { 2 - 6 } Ground cover (\%) & March 30, 2011 & June 8, 2011 & August 18, 2011 & October 24, 2011 & March 16, 2012 \\
\hline Bare soil & $13.8 \pm 6.2 \mathrm{a}$ & $7.8 \pm 2.8 \mathrm{a}$ & $5.8 \pm 1.5 \mathrm{a}$ & $4.5 \pm 2.0 \mathrm{a}$ & $31.5 \pm 1.25 \mathrm{~b}$ \\
Bryophytes & $59.8 \pm 7.6 \mathrm{a}$ & $26.2 \pm 6.2 \mathrm{~b}$ & $28.8 \pm 8.3 \mathrm{~b}$ & $35.2 \pm 2.8 \mathrm{ab}$ & $29.0 \pm 5.4 \mathrm{~b}$ \\
Lichens & $2.25 \pm 0.25$ & $3.5 \pm 1.0$ & $2.0 \pm 0.7$ & $1.2 \pm 0.2$ & $2.0 \pm 0.4$ \\
Annual herbs & $16.8 \pm 2.7 \mathrm{ab}$ & $10.8 \pm 1.1 \mathrm{ab}$ & $7.5 \pm 1.7 \mathrm{a}$ & $18.2 \pm 3.2 \mathrm{~b}$ & $9.5 \pm 1.8 \mathrm{ab}$ \\
Perennial herbs & $26.5 \pm 6.3 \mathrm{a}$ & $68.8 \pm 4.2 \mathrm{bc}$ & $90.0 \pm 6.5 \mathrm{c}$ & $56.2 \pm 10.2 \mathrm{~b}$ & $45.8 \pm 3.2 \mathrm{ab}$ \\
Proportion of vegetation cover $(\%)$ & & & & $17.5 \pm 3.7 \mathrm{ab}$ \\
Annuals & $41.2 \pm 10.4 \mathrm{a}$ & $13.7 \pm 1.6 \mathrm{~b}$ & $7.9 \pm 1.8 \mathrm{~b}$ & $26.0 \pm 5.6 \mathrm{ab}$ & $11.8 \pm 3.1 \mathrm{abc}$ \\
Non-mycorrhizal species & $17.0 \pm 1.6 \mathrm{ab}$ & $9.6 \pm 1.2 \mathrm{bc}$ & $7.9 \pm 1.4 \mathrm{c}$ & & $18.7 \pm 1.9 \mathrm{a}$ \\
\hline
\end{tabular}

enrichment in NLFA 16:1 $\omega 5$, indicating AM fungi, varied throughout the year $\left(\mathrm{F}_{4,17}=8.38, p<0.001\right.$, 9 days after labelling) with ${ }^{13} \mathrm{C}$ enrichment in June and August twice as high as compared to March, in both 2011 and 2012 (Fig. 1a). When enrichment was highest, in June and August, there was a tendency for higher enrichment on day 9 as compared to day 5. The saprotrophic fungal indicator PLFA 18:2w6,9 also received considerable amounts of plant-derived $C$; at some time-points receiving even higher enrichment than AM fungi and consistently more than bacterial PLFAs (Fig. 1b). There was no significant temporal variation in

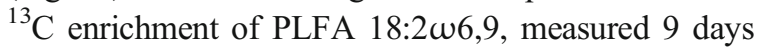
after labelling, but ${ }^{13} \mathrm{C}$ enrichment tended to be highest in August. In August and October significantly more plant-derived C was incorporated into PLFA 18:2w6,9 after 9 days as compared to 5 days after labelling $\left(\mathrm{t}_{3}=\right.$ $-7.47, p<0.005$, and $\mathrm{t}_{2}=-5.02, p<0.05$, respectively). Bacterial PLFAs showed ${ }^{13} \mathrm{C}$ enrichment throughout the season, but almost one magnitude lower enrichment compared to AM fungi and saprotrophic fungi (Fig. 1). Only little temporal variation in ${ }^{13} \mathrm{C}$ enrichment was seen for bacterial PLFAs, and no significant difference was found between day 5 and day 9 .

Bacterial biomass and saprotrophic fungal biomass, indicated by PLFAs, and AM fungal biomass, indicated by NLFA 16:1 $\omega 5$, measured 9 days after labelling, did not change significantly over the year (Fig. 2a-c). Growth rates showed temporal variation for both saprotrophic fungi and bacteria $\left(\mathrm{F}_{4,25}=4.83, p=\right.$ 0.005 , and $\mathrm{F}_{4,25}=10.84, p<0.001$, respectively,
Fig. 3a, b). The saprotrophic fungal growth rate was lowest in March 2011 and peaked in August. The bacterial growth rate also peaked in August but was lowest in October.

Plant species composition differed between the different sampling times both along the first and the second axis from the CA (Fig. 4, $\mathrm{F}_{1.8}=22.3, \mathrm{p}<0.005, \mathrm{~F}_{1.5}=$ $12.6, p<0.05$, respectively), but the two sampling times in March did not differ along PC 1. Species composition in March was more dominated by mosses, while grasses were more abundant in June and August, although the moss Hypnum cupressiforme was the most dominant species at all time points (Table S-1). In March 2011 and 2012, substantial parts of the soil were bare (Table 1). The plants classified as winter annuals were most common in March and October (i.e. spring and autumn; Bromus hordeaceus, Cerastium semidecandrum, Erophilia verna, and Trifolium campestre), while plants classified as being both winter and summer annual plants were found year-round (Arenaria serpyllifolia, Erodium cicutarium and Geranium molle). Several of the plants classified as winter annual plants are non-mycorrhizal, while most perennial plants are arbuscular mycorrhizal (Table S-1). The proportion of non-mycorrhizal species was highest in March 2012, followed by March 2011. The proportion of annual species was highest in March 2011, but was also high in October the same year (Table 1).

Both $\mathrm{NH}_{4}{ }^{+}$and $\mathrm{NO}_{3}{ }^{-}$differed slightly over the course of the experiment $\left(\mathrm{F}_{2}=4.69, \mathrm{~F}_{4}=4.57\right.$, respectively, both $\mathrm{p}<0.05$ ), with less $\mathrm{NH}_{4}{ }^{+}$in June compared 

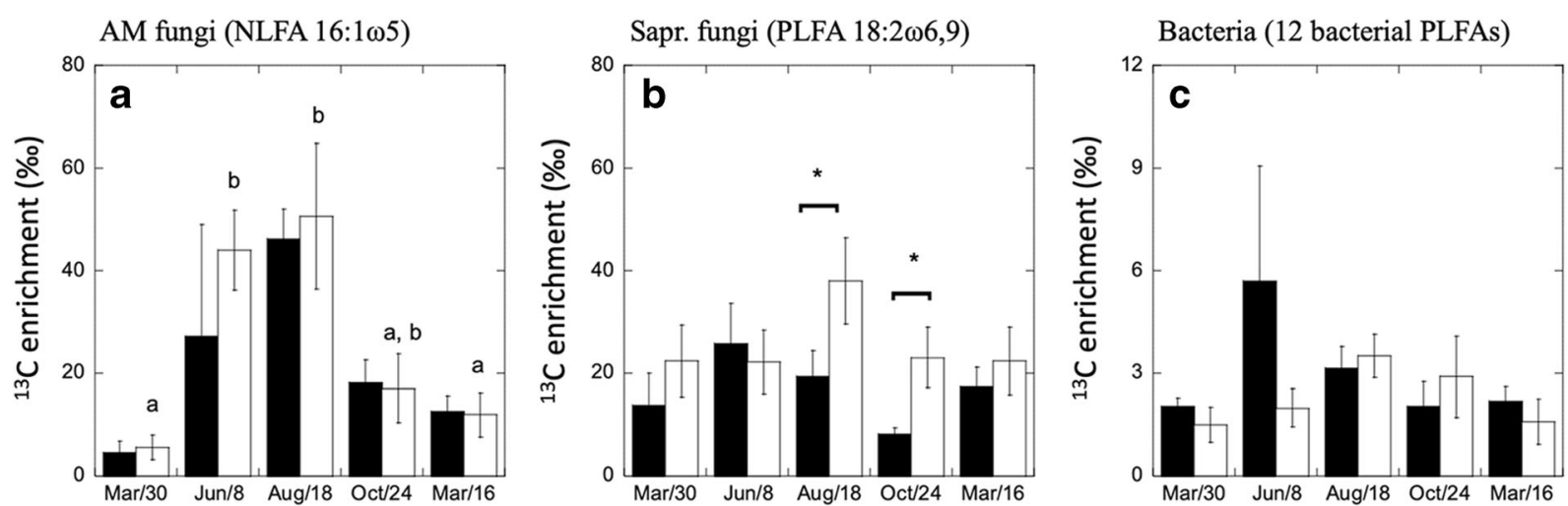

Fig. 1 Enrichment of plant-derived ${ }^{13} \mathrm{C}$ over the year, into (a) arbuscular mycorrhizal fungi, indicated by NLFA 16:1 $1 \omega 5$, (b) saprotrophic fungi, indicated by PLFA 18:2w6,9 (c) bacteria, indicated by the sum of 12 bacterial PLFAs. Black bars $=5$ days after labelling, and open bars $=9$ days after labelling. Different letters indicate significant difference $(p<0.05)$ in enrichment at

to March 2012 and more $\mathrm{NO}_{3}{ }^{-}$in October 2011 compared to March 2012 (Table 2). The peak in $\mathrm{NH}_{4}{ }^{+}$ occurred in March 2012, when the $\mathrm{NO}_{3}{ }^{-}$was lowest, while $\mathrm{NO}_{3}{ }^{-}$peaked in August. Soil moisture was lowest in June and highest in March $2011\left(\mathrm{~F}_{4}=28.15\right.$, $p<0.001$, Table 2).

\section{Discussion}

We found temporal difference between AM fungi, saprotrophic fungi and bacteria differ in how much recently-fixed $\mathrm{C}$ they receive from plants. There was a clear difference between AM fungi and saprotrophic fungi, in the turnover of recently-fixed $\mathrm{C}$ in the studied semi-natural temperate grassland, and between $\mathrm{C}$ flow day 9 , tested with one-way ANOVA and Tukey post hoc test. * = significant difference $(p<0.05)$ between sampling days (paired ttest). Values $(n=3-6 ; \pm \mathrm{SE})$ were log transformed prior to analyses. Measurements could not be achieved in some of the samples due to too low amounts for isotopic analysis

from plants to microbes and microbial saprotrophic activity. This emphasise the importance of considering the whole year when studying or modelling effects of global warming on ecosystem $\mathrm{C}$ cycling (Kreyling et al. 2019). The microbial community in the semi-natural grassland in this study was strongly influenced by nutrient limitation (Birgander et al. 2014). Plants and saprotrophic microorganisms are known to compete for $\mathrm{N}$ in several types of ecosystems (Kaye and Hart 1997; Kuzyakov and Xu 2013), but temporal niche separation in the demand of $\mathrm{N}$ for plants and microbes have been suggested to reduce the competition (Hodge et al. 2000; Kuzyakov and Xu 2013). Lowest concentration of inorganic $\mathrm{N}$ was found in June, when plant demand was likely to be high. This in addition to the seasonal vegetation changes we observed, highlight the
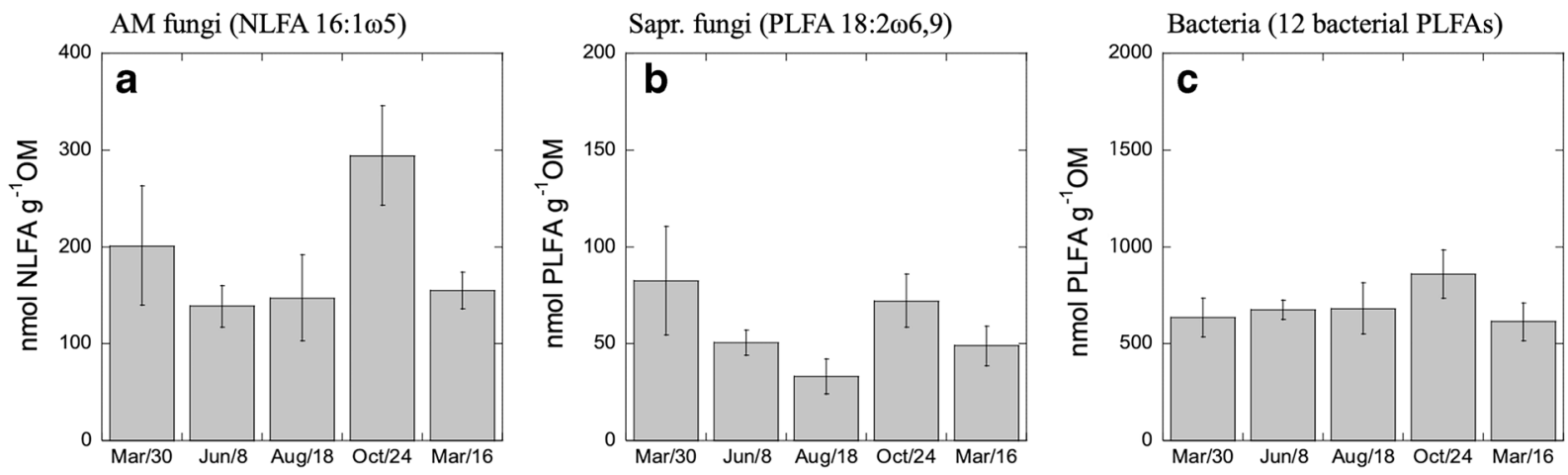

Fig. 2 Biomass of (a) arbuscular mycorrhizal fungi, indicated by NLFA 16:1 $\omega 5$, (b) saprotrophic fungi indicated by PLFA 18:2 266 and (c) bacterial, indicated by the mean of 12 bacterial PLFAs, from March 2011 to March 2012. None of the biomass values

differed significantly over the year. Values represent mean of 6 replicates \pm SE for (b) and (c), but only 3-6 replicates in (a) due to too low amounts 


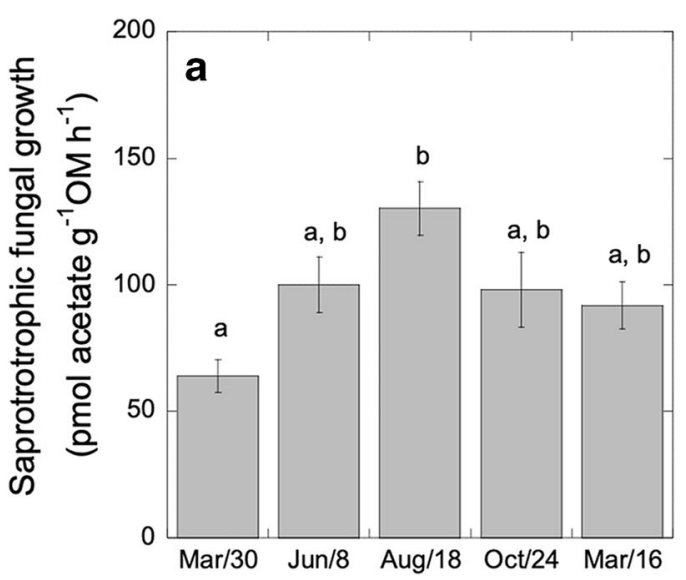

Fig. 3 Temporal variation in growth for (a) saprotrophic fungi and for (b) bacteria, from March 2011 to March 2012. Different letters indicate significant difference in growth at the different times $(p<0.05)$, investigated with ANOVA and Tukey post hoc

importance of considering the whole year when studying plant-microbe interactions and how these interactions influence climate change effects (Birgander et al. 2017; Kreyling 2010; Kreyling et al. 2019). Still, we should keep in mind that the present study was replicated within a rather homogenous part of a semi-natural grassland, and further studies that replicate across environmental gradients would significantly contribute to the knowledge in this field.

Microbial biomass did not change significantly over the year for any of the microbial groups. Hence, our hypothesis, that a high $\mathrm{C}$ flow from plants to AM fungi

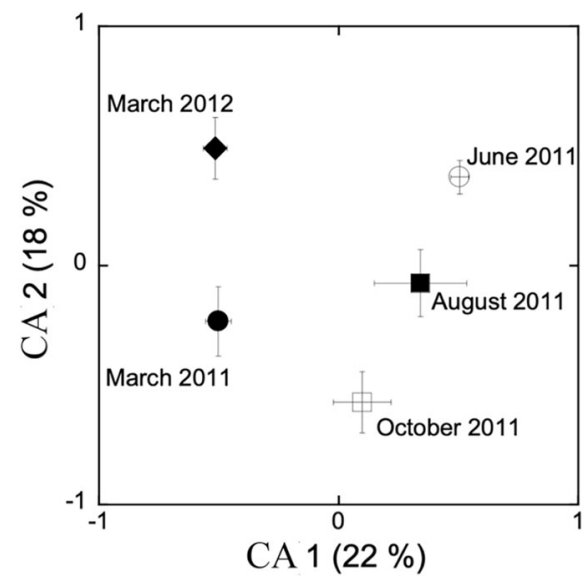

Fig. 4 Correspondence analysis (CA) of the plant species composition along the first two axes, at five time points (March 2011 closed circle, June 2011 open circle, August 2011 closed square, October 2011 open square, and March 2012 closed diamond). Sum of all eigenvalues $=1.149$. Values presented are mean of 4 $\pm \mathrm{SE}$

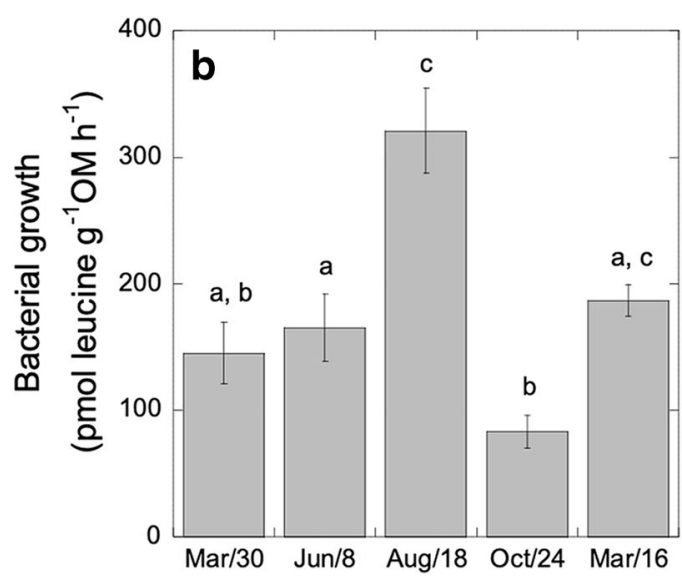

test. Values were log transformed in statistical analysis to fulfil criteria of equal variance. Values represents mean of 6 replicates \pm SE

would be followed by an increase in biomass, was not supported. However, there was a tendency for increased AM fungal biomass (storage lipids) in late autumn, possibly due to increased $\mathrm{C}$ input to $\mathrm{AM}$ fungi during the summer. Most likely, high biomass during the winter, particularly that of AM fungi, consists of a large body of less active biomass diluting the response in biomass estimates (Blagodatskaya and Kuzyakov 2013). The $\mathrm{C}$ flow from plants to soil microorganisms has previously been shown not to correlate with temperature (Birgander et al. 2017). Lack of correlation between biomass and activity (e.g. growth) for saprotrophic fungi and bacteria could indicate that changes in activity relates more to changes in turnover rates and does not therefore lead to changes in biomass (Rousk and Bååth 2011). In addition, soil freezing may influence the activity of fungivores such as microarthropods and nematodes in the soil (Sulkava and Huhta 2003). The chosen signature compound for

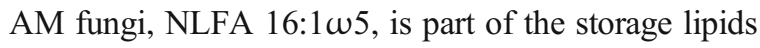
and may not be related directly to biomass. However, earlier studies have shown that this compound is more sensitive as an indicator of AM fungal mycelium (Olsson et al. 1995) and it therefore can be expected to have a higher "signal to noise" ratio in environmental samples. Furthermore, since the NLFA 16:1 w5 constitutes a major energy storage and energy transfer component in AM fungal mycelium (Van Aarle and Olsson 2003), it is thus not surprising that its content correlate well with the amount of viable mycelium (Ven et al. 2020) and root colonisation, although this correlation 
Table 2 Variation in environmental factors. Different letters indicate significant difference between time points $(p<0.05)$, tested with one-way ANOVA and Tukey post hoc test. For soil moisture and soil organic matter, a mean of 24 samples \pm SE is presented. For $\mathrm{NH}_{4}{ }^{+}$and $\mathrm{NO}_{3}{ }^{-}$, the mean of 6 replicates $\pm \mathrm{SE}$ is presented

\begin{tabular}{|c|c|c|c|c|c|}
\hline & March 30 & June 8 & August 18 & October 24 & March 16 \\
\hline Mean air temperature the week before $\left({ }^{\circ} \mathrm{C}\right)$ & 4.1 & 15.1 & 15.9 & 7.6 & 5.3 \\
\hline Soil moisture ( $\mathrm{mg} \mathrm{g}^{-1}$ soil) & $157 \pm 9 \mathrm{a}$ & $54 \pm 8 b$ & $106 \pm 5 \mathrm{c}$ & $117 \pm 5 \mathrm{c}$ & $117 \pm 7 \mathrm{c}$ \\
\hline Organic matter ( $\mathrm{mg} \mathrm{g}^{-1}$ soil) & $62 \pm 5 \mathrm{a}$ & $31 \pm 12 b$ & $37 \pm 2 b$ & $36 \pm 3 b$ & $45 \pm 3 \mathrm{a}, \mathrm{b}$ \\
\hline $\mathrm{NH}_{4}^{+}\left(\mu \mathrm{g} \mathrm{g}^{-1}\right.$ soil $)$ & & $2.1 \pm 0.2 \mathrm{a}$ & $3.2 \pm 0.4 \mathrm{a}, \mathrm{b}$ & & $3.5 \pm 0.4 \mathrm{~b}$ \\
\hline $\mathrm{NO}_{3}{ }^{-}\left(\mu \mathrm{g} \mathrm{g}^{-1}\right.$ soil $)$ & & $0.42 \pm 0.06 \mathrm{a}, \mathrm{b}$ & $0.84 \pm 0.23 \mathrm{a}$ & & $0.25 \pm 0.06 \mathrm{~b}$ \\
\hline
\end{tabular}

differs between AM fungal species (Van Aarle and Olsson 2003).

$\mathrm{C}$ allocation to AM fungi showed temporal variation, which was in accordance with our hypothesis. The highest ${ }^{13} \mathrm{C}$ enrichment in AM fungi was seen in June and August, the two warmest months in our study, representing summer. Plants can allocate $\mathrm{C}$ to $\mathrm{AM}$ fungi when the symbiosis is particularly beneficial (Bever et al. 2009). AM fungi have therefore been suggested to benefit from low nutrient conditions (Anderson et al. 1984), potentially due to an increased dependence of, and preferential $\mathrm{C}$ allocation from nutrient limited plants. In contrast to AM fungi, saprotrophic fungi showed little temporal variation in ${ }^{13} \mathrm{C}$ enrichment. The $\mathrm{C}$ flow, however, was in the same range as the $\mathrm{C}$ flow to AM fungi, and the enrichment was about six times higher in the PLFA signature for saprotrophic fungi than average bacterial PLFAs. It may seem strange that saprotrophic fungi acquire such a large proportion of the plant-derived $\mathrm{C}$ during the whole year, but saprotrophic fungi have been suggested to thrive during the colder parts of the year (Bardgett et al. 1999; Lipson et al. 2002).

The high enrichment of recently-fixed $\mathrm{C}$ in saprotrophic fungi contrasted with the assumption that bacteria dominate saprotrophic activity in the rhizosphere (Wardle et al. 2004), but is in line with recent studies indicating that saprotrophic fungi are more important than bacteria in the turnover of rhizosphere $\mathrm{C}$ (Birgander et al. 2017; Pausch et al. 2016; Streit et al. 2014). The substantial amount of plant-derived $C$ in saprotrophic fungi indicates a close connection between saprotrophic fungi and plants. However, the PLFA indicator we used for saprotrophic fungi (PLFA $18: 2 \omega 6,9)$ is common for all ascomycetes and basidiomycetes, which also include some root endophytes. Dark septate endophytes, common in forbs and grasses in most terrestrial ecosystems (Read and Haselwandter 1981) may therefore also contribute to enrichment in PLFA 18:2 $\omega 6,9$. Little is known about these endophytic fungi and their contribution to turnover of rhizosphere $\mathrm{C}$, and studies on their functional role, including studies on the saprotrophic and symbiotic activities in this group, would be very informative.

Neither bacteria nor saprotrophic fungi showed any temporal variation in ${ }^{13} \mathrm{C}$ enrichment, as judged from the chosen signature PLFAs. Overall, the ${ }^{13} \mathrm{C}$ enrichment in bacteria was lower than the enrichment in AM and saprotrophic fungi. Both bacterial and saprotrophic fungal growth rates varied throughout the year with highest growth in August, which is in accordance with previous studies (Birgander et al. 2014). We found little temporal variation in the $\mathrm{C}$-flow from plants to microorganisms, but a clear temporal variation in their growth rates. This indicates that other $\mathrm{C}$ sources, such as litter and soil organic matter, are tentatively more important drivers of soil respiration during the warmer season.

The $\mathrm{C}$ flow from plants to different groups of microorganisms did not differ due to length of the chase period - except for saprotrophic fungi in August and October. From a previous labelling study at a cold time of the year, we know that the peak in ${ }^{13} \mathrm{C}$ enrichment occurs before 5 days after labelling for all groups (Birgander et al. 2017). As discussed above, seasonality influences the activity of plants and thus probably the timing of C flow from plants to microorganisms as well (Kuzyakova and Gavrichkova 2010). For example, five days after a pulse in summer does not correspond to five days after a pulse in spring, and this obscures differences between sampling days.

We conclude that the flow of plant-derived $\mathrm{C}$ to soil microorganisms in temperate grassland may show significant temporal variation. The $\mathrm{C}$ allocation to $\mathrm{AM}$ fungi peaks in the warmer part of the year (August in 
our study), while during the colder parts of the year (March and October in our study), the highest proportion of the plant-derived $\mathrm{C}$ flows to saprotrophic fungi. Winter annual plants, which are also active during the colder parts of the year, could be one explanation for the continuous $\mathrm{C}$ flow to saprotrophic fungi. There is a clear temporal difference between AM fungi and saprotrophic fungi, while bacteria seem to be a less influential player in the turnover of rhizosphere $\mathrm{C}$ in the studied seminatural temperate grassland. Further studies are needed to show if similar variation is found across ecological gradients in grasslands, and other types of vegetation. The differences in $\mathrm{C}$ flow from plants to different groups of microorganisms in the rhizosphere and their responses to seasonal climate variation are important in predicting their response to climate change. Earlier studies have shown that warmer winters may stimulate mycorrhizal C-flow in grasslands (Birgander et al. 2017) and may favour more productive plant species (Keyling et al. 2019). Warmer winters can thus be expected to fundamentally influence grassland plant communities, and therefore have implications for conservation biology as well as ecosystem $\mathrm{C}$ sequestration.

Supplementary Information The online version contains supplementary material available at https://doi.org/10.1007/s11104021-04854-8.

Acknowledgements We thank Nicholas Rosenstock, and Johannes Rousk for valuable discussion, and Johannes Rousk and Cassandra Karlsson for appreciated comments on an earlier draft of the manuscript. This study was supported by grants from the Swedish Research Council to P.A.O. and The Royal Physiographic Society in Lund to J.B.

Authors' contributions All authors contributed to the study conception and design. Material preparation, data collection and analysis were performed by Johanna Birgander with supervision from Pål Axel Olsson. The first draft of the manuscript was written by Johanna Birgander and all authors commented on previous versions of the manuscript. All authors read and approved the final manuscript.

Funding Open Access funding provided by Lund University. This study was supported by grants from the Swedish Research Council to P.A.O. and The Royal Physiographic Society in Lund to J.B.Data availabilityThe raw data will be made available by publishing a spreadsheet along with this manuscript.

\section{Declarations}

Ethics approval and consent to participate We have no potential conflicts of interest.
Consent for publication All authors have agreed on submission of this manuscript to Plant and Soil for publication.

Competing interests We have no competing interest to declare.

Open Access This article is licensed under a Creative Commons Attribution 4.0 International License, which permits use, sharing, adaptation, distribution and reproduction in any medium or format, as long as you give appropriate credit to the original author(s) and the source, provide a link to the Creative Commons licence, and indicate if changes were made. The images or other third party material in this article are included in the article's Creative Commons licence, unless indicated otherwise in a credit line to the material. If material is not included in the article's Creative Commons licence and your intended use is not permitted by statutory regulation or exceeds the permitted use, you will need to obtain permission directly from the copyright holder. To view a copy of this licence, visit http://creativecommons.org/licenses/by/4.0/.

\section{References}

Alm J, Saarnio S, Nykänen H, Silvola J, Martikainen PJ (1999) Winter $\mathrm{CO}_{2}, \mathrm{CH}_{4}$ and $\mathrm{N}_{2} \mathrm{O}$ fluxes in some natural and drained boreal peatlands. Biogeochemistry 44:163-186

Anderson RC, Liberta AE, Dickman LA (1984) Interaction of vascular plants and vesicular-arbuscular mycorrhizal fungi across a soil moisture-nutrient gradient. Oecologia 64:111117

Andresen LC, Michelsen A (2005) Off-season uptake of nitrogen in temperate heath vegetation. Oecologia 144:585-597

Bååth E (2001) Estimation of fungal growth rates in soil using ${ }^{14} \mathrm{C}$ acetate incorporation into ergosterol. Soil Biol Biochem 33: 2011-2018

Bååth E, Pettersson M, Söderberg KH (2001) Adaptation of a rapid and economical microcentrifugation method to measure thymidine and leucine incorporation by soil bacteria. Soil Biol Biochem 33:1571-1574

Bárcena-Moreno G, Gómez-Brandón M, Rousk J, Bååth E (2009) Adaptation of soil microbial communities to temperature: comparison of fungi and bacteria in a laboratory experiment. Glob Change Biol 15:2950-2957

Bardgett RD, Lovell RD, Hobbs PJ, Jarvis SC (1999) Seasonal changes in soil microbial communities along a fertility gradient of temperate grasslands. Soil Biol Biochem 31:10211030

Bardgett RD, Streeter TC, Bol R (2003) Soil microbes compete effectively with plants for organic-nitrogen inputs to temperate grasslands. Ecology 84:1277-1287

Bever JD, Richardson SC, Lawernce BM, Holmes J, Watson M (2009) Preferential allocation to beneficial symbiont with spatial structure maintains mycorrhizal mutualism. Ecol Lett 12:13-21

Birgander J, Reischke S, Jones DL, Rousk J (2013) Temperature adaptation of bacterial growth and ${ }^{14} \mathrm{C}$-glucose 
mineralisation in a laboratory study. Soil Biol Biochem 65: 294-303

Birgander J, Rousk J, Olsson PA (2014) Comparison of fertility and seasonal effects on grassland microbial communities. Soil Biol Biochem 76:80-89

Birgander J, Rousk J, Olsson PA (2017) Warmer winters increase the rhizosphere carbon flow to mycorrhizal fungi more than to other microorganisms in a temperate grassland. Glob Change Biol 23:5372-5382

Blagodatskaya E, Kuzyakov Y (2013) Active microorganisms in soil: critical review of estimation criteria and approaches. Soil Biol Biochem 67:192-211

Brooks PD, Schmidt SK, Williams MW (1997) Winter production of $\mathrm{CO}_{2}$ and $\mathrm{N}_{2} \mathrm{O}$ from alpine tundra: environmental controls and relationship to inter-system $\mathrm{C}$ and $\mathrm{N}$ fluxes. Oecologia 110:403-413

Campbell JL, Mitchell MJ, Groffman PM, Christenson LM, Hardy JP (2005) Winter in northeastern North America: a critical period for ecological processes. Front Ecol Environ 3:314322

Clein JS, Schimle JP (1995) Microbial activity of tundra and taiga soils at sub-zero temperatures. Soil Biol Biochem 27:12311234

Flanagan LB, Johnson BG (2005) Interacting effects of temperature, soil moisture and plant biomass production on ecosystem respiration in a northern temperate grassland. Agric For Meteorol 130:237-253

Frostegård Å, Bååth E (1996) The use of phospholipid fatty acid analysis to estimate bacterial and fungal biomass in soil. Biol Fertil Soils 22:59-56

Frostegård Å, Tunlid A, Bååth E (1991) Microbial biomass measured as total lipid phosphate in soils of different organic content. J Microbiol Meth 14:151-163

Frostegård Å, Bååth E, Tunlid A (1993) Shifts in the structure of soil microbial communities in limed forest as revealed by phospholipid fatty acid analysis. Soil Biol Biochem 25:723730

Fry EL, Manning P, Macdonald C, Hasegawa S, De Palma A, Power SA, Singh BK (2016) Shifts in microbial communities do not explain the responses of grassland ecosystem function to plant functional composition and rainfall change. Soil Biol Biochem 92:199-210

Grime JP, Hodgson JG, Hunt R (1996) Comparative plant ecology - a functional approach to common British species. Chapman and Hall, Great Britain

Groffman PM, Driscoll CT, Fahey TJ, Hardy JP, Fitzhugh RD, Tierney GL (2001) Colder soils in a warmer world: a snow manipulation study in a northern hardwood forest ecosystem. Biogeochemistry 56:135-150

Harley JL, Harley EL (1987) A check-list of mycorrhiza in the British Flora. New Phytol (Suppl) 105:1-102

Hodge A, Robinson D, Fitter A (2000) Are microorganisms more effective than plants at competing for nitrogen? Trends Plant Sci 5:304-308

Jones SE, Lennon JT (2010) Dormancy contributes to the maintenance of microbial diversity. Proceedings of the National Academy of Science USA 107:5881-5886

Jones A, Montanarella L, Jones R (eds) (2005) Soil atlas of Europe. European Soil Bureau Network, European Commission, Luxembourg
Kaye JO, Hart SC (1997) Competition for nitrogen between plants and soil microorganisms. Trends Ecol Evol 12:139-143

Kreyling J (2010) Winter climate change: a critical factor for temperate vegetation performance. Ecology 91:1939-1948

Kreyling J, Grant K, Hammerl V, Arfin-Khan MAS, Malyshev AV, Penuelas J, Pritsch K, Sardans J, Schloter M, Schuerings J, Jentsch A, Beierkuhnlein C (2019) Winter warming is ecologically more relevant than summer warming in a cooltemperate grassland. Sci Rep-UK 9:14632

Kuzyakov Y, Xu X (2013) Competition between roots and microorganisms for nitrogen: mechanisms and ecological relevance. New Phytol 198:656-669

Kuzyakova Y, Gavrichkova O (2010) Time lag between photosynthesis and carbon dioxide efflux from soil: a review of mechanisms and controls. Glob Change Biol 16:3386-3406

Larsen K, Ibrom A, Jonasson S, Michelsen A, Beier C (2007) Significance of cold-season respiration and photosynthesis in a subarctic heath ecosystem in northern Sweden. Glob Change Biol 13:1498-1508

Lekberg Y, Rosendahl S, Michelsen A, Olsson PA (2013) Seasonal carbon allocation to arbuscular mycorrhizal fungi assessed by microscopic examination, stable isotope probing and fatty acid analysis. Plant Soil 368:547-555

Lipson DA, Schadt CW, Schmidt SK (2002) Changes in soil microbial community structure and function in an alpine dry meadow following spring snow melt. Microbial Ecol 43:307-314

Lloyd J, Taylor JA (1994) On the temperature dependence of soil respiration. Funct Ecol 8:315-323

Makoto K, Kajimoto T, Koyama L, Kudo G, Shibata H, Yanai Y, Cornelissen JHC (2014) Winter climate change in plant-soil systems: summary of recent findings and future perspectives. Ecol Res 29:593-606

Olsson PA, Johnson NC (2005) Tracking carbon from the atmosphere to the rhizosphere. Ecol Lett 8:1264-1270

Olsson PA, Bååth E, Jakobsen I, Söderström B (1995) The use of phospholipid and neutral lipid fatty-acids to estimate biomass of arbuscular mycorrhizal fungi in soil. Mycol Res 99:623629

Olsson PA, Francis R, Read DJ, Söderström B (1998) Growth of arbuscular mycorrhizal mycelium in calcareous dune sand and its interaction with other soil microorganisms as estimated by measurement of specific fatty acids. Plant Soil 201:9 16

Pausch J, Kramer S, Scharroba A, Scheunemann N, Butenschoen O, Kandeler E, Marhan S, Riederer M, Scheu S, Kuzyakov Y, Ruess L (2016) Small but active - pool size does not matter for carbon incorporation in below-ground food webs. Funct Ecol 30:479-489

Read DJ, Haselwandter K (1981) Observations on the mycorrhizal status of some alpine plant communities. New Phytol 88: 341-352

Rousk J, Bååth E (2011) Growth of saprotrophic fungi and bacteria in soil. FEMS Microbiol Ecol 78:17-30

Rousk J, Brooks PC, Bååth E (2009) Contrasting soil pH effects on fungal and bacterial growth suggest functional redundancy in carbon mineralization. Appl Environ Microbiol 75: $1589-1596$

Streit K, Hagedorn F, Hiltbrunner D, Portmann M, Saurer M, Buchmann N, Wild B, Richter A, Wipf S, Siegwolf RW 
(2014) Soil warming alters microbial substrate use in alpine soil. Glob Change Biol 20:1327-1338

Sulkava P, Huhta V (2003) Effects of hard frost and freeze-thaw cycles on decomposer communities and $\mathrm{N}$ mineralisation in boreal forest soil. Appl Soil Ecol 22:225-239

Ter Braak CJF, Smilauer P (2002) CANOCO reference manual and CanocoDraw for windows User's guide: software for canonical community ordination (version 4.5). Microcomputer Power, Ithaca, NY, USA

Tibbett M, Cairney JWG (2007) The cooler side of mycorrhizas: their occurrence and functioning at low temperatures. Can J Bot 85:51-62

Tunlid A, White DC (1992) Biochemical analysis of biomass, community structure, nutritional status, and metabolic activity of microbial communities in soil. In: Stotzky G, Bollag JM (eds) Soil biochemistry, vol 7. Marcel Dekker, New York, USA, pp 229-262

Tyler T, Herbertsson L, Olofsson J, Olsson PA (2021) Ecological indicator and traits values for Swedish vascular plants. Ecol Indic 120:106923
Van Aarle IM, Olsson PA (2003) Fungal lipid accumulation and development of mycelial structures by two arbuscular mycorrhizal fungi. Appl Environ Microbiol 69:6762-6767

Ven A, Verbruggen E, Verlinden MS, Olsson PA, Wallander H, Vicca S (2020) Mesh bags underestimated arbuscular mycorrhizal abundance but captured fertilization effects in a mesocosm experiment. Plant Soil 446:563-575

Walksman SA, Gerretsen FC (1931) Influence of temperature and moisture upon the nature and extent of decomposition of plant residues by microorganisms. Ecology 12:33-60

Wardle DA, Bardgett RD, Klironomos JN, Setälä H, van der Putten WH, Wall DH (2004) Ecological linkages between aboveground and belowground biota. Science 304:16291633

Publisher's note Springer Nature remains neutral with regard to jurisdictional claims in published maps and institutional affiliations. 